\title{
Bohaterowie i wrogowie młodzieży polskiej na łamach wiodących czasopism młodzieżowych okresu stalinowskiego Polski Ludowej
}

Podstawową cechą prasy okresu stalinowskiego, w tym i czasopism młodzieżowych, była indoktrynacja i dezinformacja. System przekazu propagandowego, jaki wówczas stworzono, za pierwszoplanowe zadanie uznał kształtowanie świadomości i światopoglądu społeczeństwa oraz formowanie odpowiednich postaw i zachowań. Zadanie to realizowano za pomocą zmasowanej propagandy przy jednoczesnym odcięciu odbiorców od innych źródeł informacji ${ }^{1}$. Nieodłączną funkcją ówczesnej prasy, obok tworzenia atmosfery aklamacji dla poczynań władzy, było kreowanie bohaterów i wrogów współczesności, co było zresztą zgodne z lansowaną teorią walki klasowej. Bohaterowie i wrogowie, którzy byli tworzeni na łamach prasy młodzieżowej, prezentowali różne sfery aktywności publicznej i dla jasności narracji podzielono ich według następujących kategorii: historia i polityka współczesna, kultura, nauka, sport oraz życie codzienne.

\section{Historia i polityka współczesna}

Zgodnie z immanentną cechą komunistycznego modelu prasy, czyli pełnieniem przez nią funkcji odcinka walki ideologicznej², zamieszczane w niej artykuły kreowały zarówno historię, jak i świat rzeczywisty. W przekazie ideologicznym

* Dr, Katedra Historii Wychowania, Instytut Pedagogiki, Wydział Humanistyczny, Uniwersytet Szczeciński, 71-431 Szczecin, ul. Ogińskiego 16/17.

${ }^{1}$ R. H a b i e Is k i, Polityczna historia mediów w Polsce w XX wieku, Warszawa 2009, s. 204.

2 M. M a z u r, O człowieku tendencyjnym... Obraz nowego człowieka w propagandzie komunistycznej w okresie Polski Ludowej i PRL 1944-1956, Lublin 2009, s. 242. 
funkcjonował dychotomiczny obraz rzeczywistości z podziałem na świat postępu, pokoju i radości (kraje obozu demokracji ludowej) i świat zacofania, wojny i cierpienia (kraje demokracji zachodniej). Ludzie służący sprawie socjalizmu, również w wymiarze historycznym, byli bohaterami; ci zaś, którzy się jemu sprzeciwiali usytuowani byli po stronie wrogów. Wydarzeniom i związanym z nimi postaciom - zarówno tym historycznym, jak i tym współczesnym - nadawały odpowiednie znaczenie i interpretację. W celu uniknięcia niedomówień czytelnik otrzymywał klarowny przekaz, które z tych wydarzeń i postaci zasługuje na ocenę pozytywną, a które z nich powinny wywołać odruch sprzeciwu i pogardy.

Plejadę bohaterów historycznych otwierały postacie związane z walką narodowowyzwoleńczą, m.in.: Tadeusz Kościuszko, Edward Dembowski, Jarosław Dąbrowski. Na wdzięczność pokoleń zasługiwali również bohaterzy ruchu robotniczego: Stanisław Worcell, Ludwik Waryński, Feliks Dzierżyński, Marceli Nowotko, Julian Marchlewski, Róża Luksemburg, Marian Buczek³. W publikowanych artykułach stosowano wobec wymienionych postaci specjalne określenia, które w założeniu miały dodatkowo podkreślić ich przymioty i zasługi dla ludzkości: Julian Marchlewski był nazywany „człowiekiem, który kochał ludzi”, Feliks Dzierżyński „wiecznym płomieniem”, a Róża Luksemburg „orłem rewolucji”“. Szczególną uwagę poświęcono osobie Karola Świerczewskiego, przedstawiając jego drogę życia i walki wraz z wyraźnym wskazaniem, że powinien być dla młodzieży wzorem, „jak kochać Polskę, jak o nią walczyć, jak budować"5. Przekonywano przy tym, że tylko dzięki poświeceniu Świerczewskiego „robotnicy mogą mieszkać w nowych domach Mariensztatu, a pod Krakowem powstaje wielki ośrodek przemysłowy"6.

Z uwagi na wiek potencjalnych odbiorców treści prasowych szczególną uwagę zwrócono na symbole walki młodych: Janka Krasickiego, Stanisława Dubois i Hankę Sawicką. Wszyscy oni uosabiali cechy, które - zdaniem autorów artykułów - powinny być bliskie każdemu młodemu człowiekowi w Polsce: odwagę, poświęcenie, kierowanie się ideałami rewolucji i myślą o zjednoczeniu postępowej młodzieży?.

Listę postaci historycznych zamykała ówczesna „święta trójca”, czyli Marks, Engels i Lenin. Przedmiotem publikacji prasowych były zarówno życiorysy wspo-

3 J. S e g e I, Droga pokoleń, „Pokolenie” [dalej: P] 1952, nr 6, s. 6; T. Ku re k, O Julianie Marchlewskim, P 1951, nr 11, s. 4; te nże, Za naszą i waszą wolność walczył Julian Marchlewski, P 1950, nr 11, s. 4; Wieczny płomień nie gaśnie, P 1951, nr 28, s. 3; A. Słu cki, Bojownicy o pokój i socjalizm, P 1950, nr 3, s. 4; K. Garwol iń s k a, Towarzysz Marchlewski, „Świat Młodych” [dalej: ŚM] 1950, nr 11, s. 6-7; Patroni naszych drużyn, ŚM 1950, nr 49, s 2; O człowieku, który kochał ludzi, „Nowa Wieś” [dalej: NW] 1951, nr 12, s. 5; [K.K.], Julian Marchlewski, „Płomień” [dalej: Pł] 1950, nr 16, s. 242-243; Marian Buczek - niezłomny bojownik o Polskę Ludową, NW 1951, nr 36, s. 8; K. G ar w o liń s k a, Tak rozumiał miłość Ojczyzny towarzysz Marian Buczek - godny syn klasy robotniczej, P 1949, nr 37, s. 9.

${ }^{4}$ M. M a z u r, O człowieku..., s. 5; Wieczny płomień..., s. 3; A. Słu c ki, Bojownicy..., s. 3.

${ }^{5}$ Życie Generała Karola Świerczewskiego jest dla nas wzorem jak kochać Polskę, jak o nią walczyć, jak budować, P 1952, nr 12, s. 4; Pamięci wielkiego patrioty i żołnierza, Pł 1948, nr 17, s. 525.

${ }^{6}$ A. Bińk ow ski, O generale Walterze, P 1951, nr 12, s. 3.

7 T. K u re k, Trzy wiosenne dni. Szkic opowieści o Hance Sawickiej, P 1951, nr 11, s. 1; Ludzie naszych sztandarów, P 1948, nr 3, s. 2. 
mnianych postaci, w których specjalną uwagę zwracano na atmosferę domu rodzinnego i wpływ doświadczeń młodości oraz ich oddziaływanie na dzieje świata. Użycie zwrotu „święta trójca” nie było przypadkowe: w przekazie prasowym droga życiowa każdego z tych bohaterów utrzymana była w formie hagiograficznej, nie przypominając zwykłej biografii ${ }^{8}$. Ich dokonania - jako „twórców nowej epoki” miały być dla młodzieży nie tylko przedmiotem systematycznego studiowania, ale i inspiracją do własnych działań na rzecz budowy socjalizmu9.

Niewiele mniej miejsca poświęcano bohaterom współczesnym, zwanym często "dumą epoki”: Józefowi Stalinowi, Mao Tse-tungowi, Bolesławowi Bierutowi ${ }^{10}$. Wszyscy oni zasługiwali na nimb wiecznej sławy i byli - zgodnie z intencją propagandystów - gotowymi wzorcami do naśladowania. Nie sposób wymienić tutaj wszystkich zalet, które zarezerwowano dla wymienionych bohaterów, a zwłaszcza Stalina. Pisano o nim jako o „chorążym pokoju”, „geniuszu myśli”, „geniuszu rewolucji”, „nieśmiertelnym nauczycielu młodzieży”11. Co więcej, kult dla jego osoby nie zakończył się wraz z jego śmiercią. Z uporem twierdzono, że ,jego postać, jego życie pełne znoju i trudów, wypełnione walką o zwycięstwo ideałów Partii Komunistycznej jest dla młodzieży świata wzorem hartu, ofiarności, bezgranicznego oddania sprawie szczęścia prostego człowieka, sprawie komunizmu"12. Dobre słowo kierowano też pod adresem rodzimego bohatera - Bolesława Bieruta, określając go najczęściej jako „wodza i nauczyciela [...] narodu”13 oraz „człowieka, który prowadzi [...] do nowych zwycięstw"14.

Zgodnie ze wspomnianą już zasadą dychotomii, po drugiej stronie znajdowali się wrogowie, a więc ludzie zasługujący na pogardę i nienawiść. W przypadku historii posługiwano się przeważnie antybohaterem zbiorowym. Byli to najczęściej kapitaliści czy właściciele ziemscy nękający klasę robotniczą czy chłopów lub przeciwnicy rewolucji, będący na usługach możnych i Watykanu. Jeżeli następowała personifikacja, to dotyczyła ona głównie żyjących jeszcze wówczas postaci z okresu międzywojennego: S. Mikołajczyka, F. Sławoj-Składkowskiego czy W. Andersa. Dla autorów artykułów prasowych byli to najczęściej „zdrajcy” i „wykolejeńcy”"15 i nie poświęcano im zazwyczaj wiele uwagi. Zdecydowanie więcej miejsca zajmowały publikacje, których przedmiotem byli aktywni politycy państw zachodnich: H. Truman, I. Eisenhower, K. Adenauer obdarzani określeniami typu: „usłużny lokaj milionerów”, „śmiertelny wróg postępu”, „adwokat agresji”,

${ }^{8}$ J. S e g e I, Dzieło Karola Marksa jest nieśmiertelne, P 1953, nr 10, s. 4; W. K r a s u c ki, Twórca nowej epoki, ŚM 1950, nr 10, s. 7.

${ }^{9}$ W. Krasucki, Twórca..., s. 7.

10 W. Wojtyg a, Nieśmiertelny nauczyciel młodzieży, „Sztandar Młodych” [dalej: SzM] 1953, nr 89, s. 3; Z. J u rk i e w i c z, Wielkie życie, P 1952, nr 16, s. 2-3; Bolesław Bierut - wódz i nauczyciel naszego narodu, NW 1952, nr 16, s. 3.

${ }_{11}$ W. W o j y g a, Nieśmiertelny ..., s. 3; B. B i e r u t, Stalin - twórca niezłomnej braterskiej jedności wolnych narodów, P 1953, nr 11, s. 3.

12 W. W oj ty g a, Nieśmiertelny..., tamże; E. L a s o t a, Duma naszej epoki, P 1952, nr 40, s. 3; Człowiek, który poprowadził Chiny do zwycięstwa, P 1950, nr 24, s. 2.

${ }^{13}$ Z. Jurki ewic z, Wielkie..., tamże.

${ }^{14}$ Bolestaw Bierut..., s. 3.

${ }^{15}$ Daremne żale, P 1952, nr 6, s. 8. 
„handlarz ludzkim życiem”16. W przeciwieństwie do chlubnych postaci z obozu socjalizmu, życiorysy wyżej wspomnianych przedstawiane były jako droga upadku. Przykładem może być tutaj postać I. Eisenhowera: „Ike Eisenhower pochodzi z bogatej rodziny niemieckich emigrantów, osiadłej w Stanach Zjednoczonych. Kształcił się na tradycjach krwawych pacyfikacji powstania bokserów w Chinach, na tradycjach żołdaków dolara. Ideałami, którymi został przepojony, są dążenia do zysku - każdą drogą, głównie drogą wojny"17. Listę wrogów współczesnej polityki uzupełniali wojskowi: D. MacArthur, O. Bradley, L. Johnson, a najczęściej stosowanymi w tym przypadku epitetami były: "dostawca mięsa armatniego" i „zawodowy podżegacz do wojny” ${ }^{18}$. Ostrze krytyki skierowane było wprawdzie w postacie polityki amerykańskiej, ale gorzkich słów nie szczędzono również i politykom z innych krajów zachodnich, np. R. Schumanowi, ówczesnemu ministrowi spraw zagranicznych Francji. Oto, co na jego temat pisał autor jednego z artykułów: „Każdy uczciwy Francuz wymawia dzisiaj z obrzydzeniem imię Roberta Schumana. Imię to stało się symbolem zdrady narodowej francuskiej burżuazji, która za amerykańskie dolary sprzedaje swój kraj”19.

Wszystkich wymienionych należało traktować jako zagrożenie zarówno w wymiarze jednostkowym, jak i zbiorowym, a jedynymi emocjami, które powinny towarzyszyć tym nazwiskom były wstręt i oburzenie.

\section{Kultura}

Kultura, określana mianem postępowej, pełniła wobec ideologii funkcję służebną. Zgodnie z zasadami promowanego wówczas realizmu socjalistycznego, zarówno twórca, jak i jego dzieło mieli podwójne do spełnienia zadanie: walkę z dekadencją Zachodu, przy równoczesnym formowaniu tzw. nowego człowieka. Postacie z dzieł socrealistycznych to byli najczęściej „bohaterzy-herosi, którzy toczyli walkę z wrogami pokoju i braterstwa, demaskowali sabotażystów, przekraczali normy pracownicze i umacniali się w słuszności światopoglądu marksistowsko-leninowskiego"20. Do ich propagowania przywiązywano ogromną wagę, gdyż na ich przykładzie młodzież miała się uczyć „postawy poświęcenia, bohaterstwa pracy i porywającej wielkości” ${ }^{21}$. „Bohaterami naszych filmów i książek” - pisano -

${ }^{16}$ [jes], „Dzień wiary”, czyli daremne żale pana Adenauera, P 1952, nr 28, s. 3; [R.R.], Rozważania mister Trumana o demokracji, P 1951, nr 40, s. 2; [A.B.], Wczoraj handlował podwiązkami, a dziś handluje ludzkim życiem, P 1950, nr 41, s. 4; [A.M.], Ujawnione zamiary, P 1953, nr 4, s. 2.

17 [A.M.], Ujawnione..., tamże.

18 A. Wa silj e w, Dostawca mięsa armatniego, P 1951, nr 50, s. 4; [Zet.], Plany, które spaliły na panewce, P 1950, nr 27, s. 2; [A.B.], Louis Johnson - minister wojny USA, P 1950, nr 32, s. 2.

19 [A.B.], Robert Schuman - minister zdrady narodowej, P 1950, nr 34, s. 2.

20 M. Fik, Kultura polska 1944-1956, [w:] Polacy wobec przemocy 1944-1956, red. B. Otwinowska, J. Żaryn, Warszawa 1996, s. 248.

${ }^{21}$ F. D u ra c z, Książka - twój przyjaciel i nauczyciel, „Nasze Koło Pracuje” [dalej: NKP] 1951, nr 5, s. 69. 
„,nie są kombinatorzy i niebieskie ptaki, a ludzie pracy: robotnik, chłop pracujący, żołnierz, inteligent"22. Należy również wziąć pod uwagę istotną cechę socrealizmu: jego twórcy nie odwzorowywali rzeczywistości, ale ją tworzyli, co oznaczało, że ich posłannictwem było „pokazywać, jakiej rzeczywistości i jakiego człowieka życzy sobie władza"23.

Rozeznanie co do tego, którzy twórcy i które dzieła zasługują na uwagę, młodzież zdobywała z lektury zamieszczanych recenzji, zachęt, czy też list zalecanych autorów. Byli to najczęściej laureaci stalinowskich nagród literackich, m.in.: J. Amado i A. Seghers ${ }^{24}$. Obok nich występowały też postacie z historii literatury polskiej i europejskiej. Literaturę polską najbardziej godnie - zdaniem publicystów - reprezentował A. Mickiewicz. Zgodnie przedstawiano go jako „pisarza postępowego”, którego „miłość do ludu [...] nakazuje nienawidzić jego gnębicieli, dyktuje ostre słowa skierowane przeciw caratowi, bankierom francuskim, klerowi" ${ }^{25}$. Z literatury obcej szczególnym uznaniem cieszyli się W. Hugo, którego cała twórczość miała być przeniknięta „szlachetną walką o lepsze jutro człowieka”26, F. Rabelais, który „występował przeciwko ciemnocie i barbarzyństwu”27 i A. Puszkin, kreślący „smutny i surowy obraz współczesnej wsi”28. Zachęcano również młodzież do poznawania twórczości pisarzy współczesnych: G. Morcinka, B. Czeszki, I. Newerly'ego, R. Emersona, H. Fasta, M. Ostrowskiego, A. Gajdara, A. Fadjejewa. M. Gorkiego. Specjalną uwagę poświęcano kreowanym przez tych twórców postaciom. Bezapelacyjnym liderem wśród literackich bohaterów młodzieżowych był Pawka Korczagin z powieści Jak hartowała się stal M. Ostrowskiego ${ }^{29}$, którego stawiano za wzór młodzieży polskiej. O pozytywnym wpływie tej postaci literackiej miały m.in. świadczyć następujące listy do redakcji: „Poznając Korczagina uczymy się walczyć z wrogami i przełamywać w nas samych wszystkie wady, które przeszkadzają nam w pracy i nauce. [...] Dziś wydaje mi się, że znam Pawkę jak brata"30. Listę bohaterów uzupełniali również: Borys, żarliwy rewolucjonista z książki Szkoła A. Gajdara; Jurek, Stacho i inni ZWM-owcy z Pokolenia B. Czeszki walczący o lepsze jutro; Paweł Własow i jego matka z powieści M. Gorkiego, odnajdujący sens swojego życia w walce rewolucyjnej; Jerzy Szczęsny zafascynowany ideami komunizmu z Pamiątki z Celulozy I. Newerly'ego oraz Aleksy Stachanow, twórca współzawodnictwa w pracy z książki C. Bobińskiej O prostym człowieku z ZSRR ${ }^{31}$.

\footnotetext{
22 [M.K.], Sprawa honoru, P 1952, nr 12, s. 3.

${ }^{23}$ M. Fik, Kultura polska..., s. 254; T. Hejnicka-Bezwińs ka, Zarys historii wychowania (1944-1989), Kielce 1996, s. 72.

${ }^{24}$ W. W o r o s z y I s ki, Pisarze dobrzy i różni, SzM 1951, nr 94, s. 2; Międzynarodowe stalinowskie nagrody pokoju, P 1953, nr 2, s. 3.

${ }^{25}$ A. Ja sińs ki, Mickiewicz - pisarz postępowy, P 1950, nr 4, s. 8; A. Za por ow ski, Dzieła wiecznie młode, P 1948, nr 1, s. 2.

${ }^{26}$ D. Ło m a cze w s ka, Gdyby tylko jeden pozostał - ja nim będę, P 1952, nr 10, s. 11.

27 [b.t.], P 1953, nr 31, s. 4.

${ }^{28}$ T. Ku rz a wa, Puszkin-prozaik, P 1952, nr 6, s. 11.

${ }^{29}$ L. Witc z a k, Pamięci Korczagina, P 1952, nr 42, s. 5; T. Konwick i, Pisarz wielkich serc, P 1951, nr 51-52, s. 13.

30 Poznałem Korczagina, P 1952, nr 45, s. 7.

${ }^{31}$ [S.N.], Co czytać, Pł 1949, nr 8, s. 127; M. G ó r a, Czytelnicy o książkach, NW 1951, nr 20 ,
} 
Pisząc o literaturze, którą propagowano na łamach prasy, nie można zapominać też o tych pisarzach, co do których istniały wątpliwości. Literaci tacy posiadali słuszne założenia, ale ich dzieła - według autorów artykułów - wymagały określonej interpretacji. Przykładem może tu być E. Orzeszkowa, która „nie zawsze stała na słusznym stanowisku. Nie widziała, że wyzysk i nędza są nieodłącznymi towarzyszami ustroju, w którym żyła, nie rozumiała rodzącej się w łonie kapitalizmu walki, nie zdawała sobie sprawy z roli, jaką w historii odgrywa proletariat”" ${ }^{2}$. Podobnie oceniano dorobek R. Reymonta, o którym pisano, że „rysował rzeczywistość w sposób realistyczny, ale bez wyciągania słusznych społecznie wniosków”, a fakt, że „związał swoje losy i swoją twórczość z burżuazją” zadecydował o przyznaniu mu nagrody $\mathrm{Nobla}^{33}$. Właściwej wykładni wymagała również powieść J. Steinbecka Myszy i ludzie, która - zdaniem publicysty „Pokolenia” - firmowała szkodliwą tezę, że w ustroju kapitalistycznym istnieje jakakolwiek szansa polepszenia bytu robotników rolnych ${ }^{34}$.

Promując kulturę postępową, nie zapomniano też o filmie, poświęcając mu specjalną rubrykę pod tytułem „Czy widzieliście ten film?”. Wśród polecanych tytułów znalazły się zarówno te, które przedstawiały życie bohaterów masowej wyobraźni, np. Dzierżyńskiego czy Świerczewskiego, a także te, które opowiadały o losach tzw. zwykłych ludzi: pionierów, kołchoźnic, przodowników pracy, ofiar obszarników i kapitalistów ${ }^{35}$.

Po drugiej stronie bieguna usytuowana została kultura wsteczna i dekadencka. Charakteryzowano ją w następujących słowach: „Czy zastanawiasz się, czytelniku, jaką książkę wypożyczasz z biblioteki? Czy zastanawiasz się, jeżeli bierzesz do ręki powieść, jaki wpływ wywrze na ciebie treść? [...] Wiesz, że inna jest miara moralności w państwach, w których określa się wartość człowieka według jego rocznych dochodów. Tam, bohaterami książek są gangsterzy, bankierzy, detektywi i córki miliarderów. [...] Recepta na powieści tego typu jest prosta: pisz o zbrodniach, ucz kraść, ucz mordować, paś niezdrową sensację - aby handel dobrze szedł"36. Charakterystyczne jest to, że właściwie żaden z bohaterów literatury wstecznej, oprócz postaci Stachowicza - zdrajcy z Młodej Gwardii, nie zasługiwał na specjalne wspomnienie. Przedstawiano za to nazwiska twórców, którzy byli odpowiedzialni za lansowanie tego typu wątpliwych bohaterów: Maxa Brandta, autora westernów powieściowych; Karola Maya tworzącego książki podróżniczo-przygodowe; Adama Nasielskiego i Adama Marczyńskiego - piszących

s. 9; [A.B.], Maksim Gorki, „Matka”, P 1949, nr 16, s. 4; [j.z.], „Pokolenie” B. Czeszki, P 1952, nr 9, s. 11; [dw], Wielka szkoła, P 1953, nr 1, s. 11; D. B a r g i eło w s k i, Głos walczącego pisarza, P 1953, nr 20, s. 10.

32 J. Ś wi dziń s ki, Przeciw ludzkiej krzywdzie, P 1951, nr 15, s. 15.

33 J. Rurawski, O Reymoncie, P 1953, nr 21, s. 10.

${ }^{34}$ A. B r a u n, J. Steinbeck „Myszy i ludzie”, P 1950, nr 9, s. 5.

${ }^{35}$ W. Li k s z a, Czy widzieliście ten film, P 1953, nr 1, s. 9; nr 5, s. 9; W. Li k s z a, Żołnierz zwycięstwa, tamże, nr 13, s. 12; M. P o g o d i n, Feliks Dzierżyński, tamże, nr 23, s. 11; J. G iż y c k i, Pierwszy film o młodzieży, P 1951, nr 4, s. 1; [Sar], Film o zwycięstwie kobiety i pracy, P 1950, nr 13, s. 13.

${ }^{36}$ [J.G.], Jak długo jeszcze widma Wallace'ów, Romańskich i Marczyńskich straszyć nas będą w prywatnych wypożyczalniach książek?, P 1950, nr 22, s. 1. 
powieści kryminalne; Edgara Wallace'a - tworzącego powieści kryminalno-awanturnicze oraz Archibalda Cronina - autora pozycji społeczno-obyczajowych ${ }^{37}$. W celu ochronienia młodzieży przed zgubnym wpływem wątpliwych dzieł kultury apelowano zarówno o systematyczną inspekcję państwowych i prywatnych wypożyczalni, jak i dopilnowanie, czy na stanowisku bibliotekarza pracuje odpowiedni człowiek ${ }^{38}$.

W ogniu krytyki znalazł się również film z krajów zachodu, o których pisano: „Dość już filmów, w których nie występuje ani jeden zwykły, normalny człowiek, dość filmów tchnących beznadziejnym pesymizmem. [...] Zamiast bajeczek o niepoczytalnych mordercach i pozbawionych pamięci neurastenikach, uświadomiony widz pragnie optymistycznych, humanistycznych filmów o prostych ludziach, normalnie i prawdziwie walczących o swoje szczęście"39. Na miano twórcy kultury małowartościowej zasłużył też rodzimy K. I. Gałczyński oraz jego „Teatrzyk ZieIona Gęś", co znalazło swój wyraz z liście do redakcji nadesłanym przez grupę ZMP-owców z koła zakładowego: „ten rodzaj dowcipu reprezentuje schyłkową, kapitalistyczną kulturę. [...]. Zwracamy się z prośbą i żądaniem, ażeby K. Gałczyński pisał tylko dla mas pracujących, w których szeregach kroczy postępowa młodzież polska"40.

Postacie z wymienionych powieści, sztuk czy filmów stanowiły - zdaniem publicystów - symbol upadku Zachodu, dobrych obyczajów, taniego sentymentalizmu i sensacji. Były również odpowiedzialne za kreowanie postaw wrogich państwu ludowemu i demoralizację młodego pokolenia.

\section{Nauka}

Podstawą filozoficzną, poznawczą i metodologiczną dociekań naukowych w omawianym czasie historycznym stał się marksizm-leninizm, a cel badań określono jako kształtowanie światopoglądu naukowego. Oznaczało to odrzucenie zarówno metafizyki, jak i idealizmu. Pisano, że praca nad kształtowaniem światopoglądu naukowego to „ukazywanie zwycięstwa materializmu nad idealizmem w świetle każdej nowej zdobyczy, każdego nowego odkrycia w nauce i technice" ${ }^{41}$. Niezbywalną częścią wspomnianej pracy była nie tylko propaganda marksistowsko-leninowska, popularyzacja wiedzy przyrodniczej, demaskowanie nienaukowych teorii, ale i walka z przesądami oraz zabobonami ${ }^{42}$. Na uznanie zasługiwali jedynie ci naukowcy, którzy spełniali powyżej określone wymogi.

${ }^{37}$ [J.G.], Jak długo..., s. 1; K. L u b e l c z y k, O kołach naukowych w szkole, P 1949, nr 34, s. 9; [W.L.], A jak jest w twojej bibliotece?, NW 1951, nr 23, s. 7.

${ }_{38}$ [W.L.], A jak jest..., s. 7; [J.G.], Jak długo..., s. 1.

39 J. Ł ę c z y c a, Filmowy kaftan bezpieczeństwa, czyli rzecz o ogłupianiu widza, P 1950, nr 21, s. 5.

40 Dla kogo pisana jest „Zielona Gęś,, P 1950, nr 20, s. 7.

41 A. D r oż dży ń s k i, O naukowy światopogląd, NKP 1953, nr 6, s. 30.

42 Tamże, s. 30-31. 
Dla potrzeb propagandy w grupie tej znalazły się również postacie historyczne, spośród których prym wiódł Mikołaj Kopernik. Nazywany był najczęściej „wielkim rewolucjonistą nauki”, „szermierzem prawdy i postępu” i "geniuszem polskiego Odrodzenia” ${ }^{3}$. Głoszono, że ,jego teoria i jego nazwisko stały się w historii symbolem postępu nauki, symbolem walki z obskurantyzmem kościoła i wszelkich wstecznych sił"44, a on sam „zadał druzgocący cios zabobonom i przesądom, przezwyciężył podstawowe błędy dawnej nauki przyrodniczej, uwolnił naukę od teologii”"45. Godne miejsce w historii nauki zajmowali też Giordano Bruno i Galileusz - twórcy postępu i przez to „ofiary ciemnoty kleru”46, a obok nich inni kontynuatorzy idei postępu: Kepler, Kartezjusz, Newton, Darwin ${ }^{47}$. Warto nadmienić, że dwóch spośród ostatnio wymienionych uczonych nie przyjmowano bezkrytycznie. Newtonowi zarzucano, że swoją naukę „próbował sztucznie naginać [...] do potrzeb kościoła anglikańskiego”48, a teoria Darwina miała być z kolei „skażona bezkrytycznym przyjęciem fałszywej i reakcyjnej teorii Malthusa"49. Ostatecznie uznano jednak, że ewentualne korzyści propagandowe przewyższają wskazane niedoskonałości i nie pomniejszają zasług obu uczonych dla postępowej nauki.

Odrębną grupę postępowych naukowców tworzyły postacie z obszaru ówczesnej nauki radzieckiej, których niezwykłe dokonania prezentowane były w niezliczonych artykułach. Byli to m.in. S. Bruchonienko i S. Czeczulin - fizjolodzy i twórcy sztucznego serca, którzy spowodowali ożywienie martwego psa ${ }^{50}$, M. Pirogow - prekursor aseptyki ${ }^{51}$, I. Pawłow - zadający cios burżuazyjnej nauce i lansowanej przez nią teorii o "nadprzyrodzonej istocie myśli"52 i O. Lepieszyńska - twórczyni teorii tworzenia się nowych komórek z bezkomórkowej substancji białkowej ${ }^{53}$. Absolutny prym na liście bohaterów nauki wiedli jednak Iwan Miczurin oraz jego uczeń Trofim Łysenko. Drugi z nich określany był mianem „czarodzieja urodzajów"54. Popularyzacji osiągnięć tych dwóch naukowców poświęcano w prasie specjalne rubryki np. „Kącik młodych Miczurinowców”55, w którym donoszono o zaskakujących wynikach upraw: wyhodowaniu pomidora szczepionego na ziemniaku, marchwi na koprze czy orzechu na kasztanie ${ }^{56}$. Równie ważna dla

43 J. Ku c z yń s ki, Geniusz polskiego Odrodzenia, P 1953, nr 23, s. 3; t e n że, Szermierz prawdy i postępu, P 1953, nr 17, s. 4; W. Kraje w s k i, Wielki rewolucjonista nauki, P 1950, nr 7, s. 12.

44 J. Ku czyń ski, Geniusz..., tamże.

45 J. Kuczyński, Szermierz..., s. 4.

46 J. Ku czyńs ki, Geniusz..., s. 3.

47 Tamże.

48 O Izaaku Newtonie, P 1951, nr 13, s. 4.

49 Życiorys rozpoczęty na pokładzie „Beagle”, P 1952, nr 6, s. 5.

50 Sztuczne serce: czy można przywrócić życie?, P 1953, nr 9, s. 9.

51 M. S ta r z y ń s k i, Pirogow - twórca chirurgii, P 1951, nr 1, s. 10.

52 J. W r o ń s k i, Nauka radziecka w służbie ludzkości i postępu, P 1950, nr 43, s. 10; W. B or k o w s k i, Przyjaciel ludzkości twórca nowoczesnej fizjologii, Pł 1949, nr 3, s. 2.

53 J. Wroński, Nauka..., s. 10; J. Dą browska, Z wizytą u Olgi Lepieszyńskiej, ŚM 1950, nr 48, s. 8.

54 Czarodziej urodzajów, ŚM 1952, nr 37, s. 6.

55 Kącik Młodych Miczurinowców, NW 1951, nr 36, s. 9.

56 [J.R.], Orzech na kasztanie, P 1952, nr 14, s. 8; J. O I b re c h t, Morele na północy, P 1950, nr 23, s. 11. 
celów propagandowych była grupa racjonalizatorów, którzy swoimi dokonaniami przyspieszali cykl produkcji, jak np. stachanowiec radziecki Kolesow - twórca szybkościowej metody skrawania przy użyciu noża tokarskiego ${ }^{57}$ czy komsomołka Żandarowa - inicjatorka zmianowego przekazywania maszyn ${ }^{58}$. Postępowi naukowcy, oprócz prowadzenia badań, mieli również obowiązek zaangażowania się na rzecz walki o pokój. Było to zgodne z głoszoną wówczas tezą, że „świat nauki nie stanowi oderwanej od życia całości [...]. Mit o apolityczności nauki, stworzony przez pseudonaukowców, pozostających na usługach imperializmu, służy wyłącznie do zamaskowania zbrodniczych celów ich nauki”’59. Szczególną uwagę poświęcono osobie fizyka Fryderyka Joliot-Curie, pracującego nad udoskonaleniem stosu atomowego i toczącego jednocześnie batalię z podżegaczami wojennymi, który jako pierwszy złożył podpis pod Apelem Sztokholmskim. Z tej też przyczyny stał się ofiarą "wściekłej nagonki prasowej” ${ }^{\circ}$. Z powodów propagandowych na życzliwą uwagę czytelnika zasługiwał również Leopold Infeld, fizyk teoretyczny, który - według autora artykułu - porzucił pracę na uniwersytecie kanadyjskim i wrócił do Polski, gdyż nie chciał dalej pracować w kraju, gdzie „nauka jest sprzedajna, gdzie wykorzystuje się ją do celów wojennych"61.

„Nauka sprzedajna” oraz "nauka na usługach imperialistów” - to były dwa najczęściej powtarzające się epitety na określenie tzw. nauki wstecznej, czyli w większości przypadków rozwijanej w krajach zachodnich. Charakterystyczne jest to, że artykułów na temat wspomnianej nauki jest niewiele. Uznano najwidoczniej, że nie zasługuje ona na wspomnienie, a jeżeli już pojawiała się jakaś publikacja, to była ona utrzymana w tonie ironiczno-demaskatorskim. Wszystkie patologie nauki burżuazyjnej przybliżano np. w ramach prasowego cyklu pod nazwą „Nauka w dolarowym sosie". Sam tytuł serii miał wskazywać na fakt, że nauka zachodnia nie jest autonomiczna, a wszystkie jej osiągnięcia służą interesom możnych. Taka zależność powodowała z kolei, że - jak to oceniał publicysta - „Wysiłki naukowców kapitalistycznych usiłujących wszelkimi sposobami przypodobać się swym mocodawcom przybierają nierzadko formy wyraźnych bredni”62. Twórcami takich „naukowych bredni" byli m.in. J. Steward kładący podwaliny pod nową naukę - fizykę socjalną, w której prawa fizyczne i chemiczne zastosował wobec społeczności ludz$k^{k i c h}{ }^{63}$, a także T. Malthus, podkreślający zależność między wzrostem demograficznym a poziomem zamożności społeczeństwa ${ }^{64}$. Przedmiotem kpin był również fakt opublikowania w "Scientific American” artykułu na temat prawdopodobieństwa wygrania w grę karcianą̨ ${ }^{65}$. Sukcesywnie umieszczano też artykuły na temat tzw. uczonych-gangsterów, czyli głównie tych, którzy swoimi odkryciami przyczyniali się do

57 P 1953, nr 15, s. 9.

58 P 1950, nr 23, s. 11.

59 D. W i e r z b i c k a, Jedność uczonych ze światem pracy gwarancją pokoju, P 1950, nr 16, s. 7.

60 Tamże; A. B iń k o w s k i, Barbarzyńcy i uczony, P 1950, nr 47, s. 3.

61 J. D ą b r o w s k a, Dwa bieguny nauki, P 1950, nr 51, s. 5.

62 Nauka w dolarowym sosie, P 1950, nr 29, s. 8.

63 Tamże.

64 Uczeni gangsterzy, P 1953, nr 20, s. 2.

65 P 1952, nr 18, s. 9. 
postępu prac nad bombą atomową. Byli to m.in.: Robert Oppenheimer, zwany ojcem bomby atomowej, Harold Urey - laureat Nagrody Nobla w dziedzinie chemii i odkrywca metody rozdzielania izotopów oraz Lawrence Hafstad, fizyk energii atomowej, odgrywający główną rolę w pracach nad udoskonaleniem stosu atomowego ${ }^{66}$.

\section{Sport}

Sport, podobnie jak pozostałe formy aktywności młodzieży w okresie stalinowskim, pełnił istotną rolę w prowadzonej wówczas ofensywie ideologicznej. Zgodnie z wolą decydentów partyjnych, kultura fizyczna miała stanowić „bardzo ważny odcinek pracy politycznej, ideowo-wychowawczej i organizacyjnej”67. Sport w ówczesnych warunkach politycznych przestał być kwestią rozwijania indywidualnych uzdolnień czy predyspozycji, a stał się jednym z obowiązków wobec ludowego państwa. Sport w Polsce Ludowej był - co bardzo często podkreślano - „sportem prawdziwym”, czyli takim, który „może się rozwijać i wznosić na wysoki poziom tylko w tych krajach, w których służy on sprawie zdrowia, szczęścia i radości człowieka, w których otoczony on jest troskliwą i wszechstronną opieką państwa, w krajach budujących pokój i socjalizm”69. Przekonywano, że jest „pomocnikiem w pracy, w nauce” i że „stał się orężem młodzieży w walce o pokój”70.

Opieka państwa, o której wspomniano, nie mogła być oczywiście bezinteresowna. Sportowcy mieli wobec obozu rządzącego obowiązki, których wypełnianiem powinni się byli wykazać i które wykraczały daleko poza zwyczajowe bicie rekordów: na łamach prasy byli oni wprawdzie kreowani na bohaterów, ale zapłatą za to stawało się wpisanie ich osiągnięć w propagandową narrację. W jednym z artykułów z 1953 r. znajdujemy taką oto relację: „Szczęśliwy ze zwycięstwa Królak niesiony na ramionach tłumów wędruje do loży honorowej. Tu zostaje przedstawiony członkom Rządu i KC Partii oraz przewodniczącemu Rady Państwa, który serdecznie ściska najlepszego kolarza na polskiej ziemi"71.

Zawodnicy byli również wykorzystywani jako gotowe wzorce sportowców państwa ludowego, prezentujący swoimi osobami męstwo, wytrzymałość, pracowitość, optymizm i ducha walki. Obowiązywały ich również określone powinności: zaangażowanie społeczno-polityczne oraz uczucie wdzięczności wobec państwa za sprawowaną nad nimi opiekę.

Wdzięczność taką wyrażał na łamach prasy m.in. Feliks Sztam w imieniu polskich bokserów, mówiąc: „Dziś wiem, że mnie, moim kolegom trenerom i zawodnikom stworzono warunki do jak najlepszego przygotowania się do wszystkich

\footnotetext{
66 J. Dąbrowsk ka, Dwa bieguny...,s. 5.

67 Tamże, s. 57; S. R z e s z o t, Nasze zadania w sporcie, NKP 1949, nr 12, s. 85.

${ }^{68}$ [J.D.], Po mistrzostwach Europy w boksie, P 1953, nr 22, s. 3.

69 Tamże.

70 [Dwajot.], U nich i u nas, ŚM 1950, nr 25, s. 2.

${ }^{71}$ M. Gó ra, Na polskich szosach, P 1953, nr 21, s. 12.
} 
imprez. Teraz trzeba tylko solidnie pracować, aby nie zawieść zaufania, jakim nas obdarzono i wykazać, że warunki jakie nam stworzyła Polska Ludowa umiemy wykorzystać"72. Zygmunt Chychła i Henryk Hadasik zapewniali zaś o swoim zaangażowaniu politycznym, włączając się w walkę o pokój. Hadasik osobiście złożył podpis pod Apelem Sztokholmskim, zaś Chychła, który był wówczas na ME w Mediolanie, walką udowadniał wyższość sportu ludowego nad kapitalistycznym ${ }^{73}$. Ze swoich obowiązków względem państwa przy okazji IV Światowego Festiwalu w Bukareszcie wywiązał się również S. Królak, donosząc: „Jestem wzruszony tym, że postawiliście m.in. na mnie - żołnierza i sportowca. Meldunek młodzieży polskiej, który przekazałem dzisiaj sztafecie czechosłowackiej, mówi o tym, że czynem popieramy słowa: pokój i przyjaźń" ${ }^{4}$.

Poczet krajowych bohaterów sportowych uzupełniały postacie z pozostałych krajów demokracji ludowej, w tym przede wszystkim genialny biegacz Emil Zatopek. Była to osoba dla propagandy bezcenna: należał do Komunistycznej Partii Czechosłowackiej, uświadamiał społecznie młodzież oraz składał socjalistyczne sportowe zobowiązania ${ }^{75}$. Systematycznie podkreślano, że „wysokie moralne wartości Zatopka są przykładem i wzorem nie tylko dla sportowców, ale dla wszystkich obywateli naszej Ojczyzny. Dlatego właśnie na wielu uroczystościach skandujemy na cześć naszej ludowej demokratycznej republiki obok nazwisk przywódców również: Zatopek! Zatopek! Zatopek!"76.

Obok powszechnie znanych rekordzistów sportowych promowano też sportowców młodych, najchętniej tych, którzy byli równocześnie przodownikami pracy czy nauki oraz należeli do organizacji młodzieżowych. Podkreślano przy okazji fakt, że łączenie różnych sfer działalności możliwe jest tylko dzięki opiece władzy ludowej ${ }^{77}$.

Przeciwwagą dla ludowego sportu był świat sportu kapitalistycznego. Pisano: „W krajach kapitalistycznych sport nie jest rozrywką, nie służy zdrowiu sportowców. Stał się jeszcze jednym źródłem dochodów dla bogatych menagerów, niby «działaczy sportowych»"78. Poświęcono mu w prasie specjalną rubrykę „Sport na Zachodzie", w której obnażano jego prawdziwe oblicze: materializm, brutalność, oszustwo. Kolejne cechy, które stały się znakiem firmowym sportu kapitalistycznego to m.in.: indywidualizm, egoizm, zazdrość, zarozumiałość, lekceważenie kolektywu ${ }^{79}$. Przy okazji przypominano czasy polskiego sportu okresu międzywojennego i na przykładzie piłki nożnej wykazywano, że był to typowy sport bur-

72 Feliks Sztam mówi o przygotowaniach do Mistrzostw Europy, P 1953, nr 4, s. 12.

${ }^{73}$ Dlaczego podpisali Apel Pokoju, P 1950, nr 21, s. 6; Rozmawiamy z mistrzem Europy, ŚM 1951, nr 23, s. 7.

${ }^{74}$ S. K rólak, List otwarty, P 1953, nr 30, s. 10.

75 J. Has, A. Jirace k, Nie maszyna lecz człowiek, P 1952, nr 32, s. 12; Emil Zatopek prosi o przyjęcie w szeregi Komunistycznej Partii Czechosłowackiej, NW 1951, nr 24, s. 13.

76 J. Has, A. Jiracek, Nie maszyna..., s. 12.

77 Iren Zsagot opowiada, P 1952, nr 31, s. 16; E. Wa s i li e w, Złoty medal Haliny Zybinej, tamże, nr 36, s. 12; J. Ros z k o, Irena Dobranowska, P 1951, nr 1, s. 12; [J.J.], Dwie rozmowy, ŚM 1950, nr 25, s. 1; Takich ludzi wychował ZMP, NW 1953, nr 29, s. 14.

${ }^{78}$ [Dwajot.], U nich..., s. 2.

79 Tamże, s. 55. 
żuazyjny: „Takie ponure obrazy - faule, były na naszych boiskach przed wojną chlebem powszednim. Nikt nie dbał wtedy o wychowanie zawodnika. Przeciwnie, grający brutalnie byli cenieni przez kierowników drużyn, trenerów i otaczani opieką, bo ich faule dawały punkty"80.

Przedstawicieli sportu kapitalistycznego przedstawiano za to dwojako: z jednej strony byli to kreatorzy zdegenerowanego świata sportu burżuazyjnego, a z drugiej jego ofiary. Pierwszą z wymienionych grup zasilili m.in.: Frank Sedgman i Francisco Segura, zwycięzcy Pucharu Davisa, którzy „za drobną opłatą w dolarowej monecie" mieli odgrywać ukartowane pojedynki przed zgromadzoną publicznością ${ }^{81}$ oraz James Fuchs, wielokrotny amerykański rekordzista świata w pchnięciu kulą, który w momencie triumfu miał liczyć dolary, które zarobił w wyniku zwycięstwa ${ }^{22}$. Systematycznie prezentowano też sylwetki tych sportowców, którzy, zdaniem publicystów, wykazywali się szczególną brutalnością lub też służyli sprawie wojny ${ }^{83}$. Donoszono również o wszelkich wypadkach w trakcie zawodów sportowych mających dowodzić, że sport w wydaniu zachodnim jest nie tylko brutalny, ale i niebezpieczny ${ }^{84}$. Prezentację sportowców z drugiej z wymienionych grup, czyli ofiar sportu kapitalistycznego łączono najczęściej z kwestią zawodowstwa, które było zarazem głównym przedmiotem krytyki ze strony publicystów. Pisano m.in.: „U nas [...] mistrz olimpijski otrzymuje tytuł zasłużonego mistrza sportu. Państwo roztacza nad nim jeszcze lepszą opiekę. U nich mistrz olimpijski idzie na zawodowstwo, by prędzej czy później stać się ofiarą gangsterskiej bandy menażerów. U nas sport jest dla ludzi, u nich dla dolarów i występku"85. Przywoływano tu przykład Jessie Owensa, który - jak pisano w prasie - „za marne centy został portierem w luksusowym hotelu"86 oraz Harry'ego Dillarda, który stał się „Czyścibutem na jednym z nowojorskich dworców"87.

\section{Życie codzienne}

Bohaterem dnia codziennego zostawał człowiek, który swoim wysiłkiem i postawą społeczną udowadniał, że zasługuje na miano dobrego obywatela Polski Ludowej. Prym wiedli przodownicy pracy, którzy nie tylko bili rekordy produkcji, ale i wdrażali myśl racjonalizatorską, tak jak np. Jan Janczak z Pruszkowa, osiągający $250 \%$ normy dzięki zastosowaniu metody Żandarowej czy Stefan

80 W. Wojte cki, Sprawa ważna $i$ aktualna, P 1953, nr 1, s. 12.

81 [ptr.], Krótkie spięcia, P 1953, nr 4, s. 12.

82 I love you, P 1950, nr 36, s. 10.

${ }^{83}$ [ptr.], Siła dolara, P 1952, nr 48, s. 12; Krótkie spięcia, P 1953, nr 9, s. 12; Sport?, P 1952, nr 33, s. 9; Mistrz ich nauczy, P 1951, nr 4, s. 12.

${ }^{84}$ [A.M.], Śmierć na torze, P 1953, nr 6, s. 2; Z. Ka s z k u r, Nagrobki, P 1952, nr 20, s. 12.

85 [W.G.], Historia ponura, P 1952, nr 47, s. 12; A. K u l e s zo w, Za kulisami zawodowego sportu, tamże, nr 20, s. 12.

86 Tu czyści buty Harry Dillard - zwycięzca olimpijski, P 1951, nr 7, s. 12.

87 Tamże. 
Gadziński (360\%), korzystający z doświadczeń radzieckich stachanowców ${ }^{88}$. Przodownikami pracy były też kobiety, które - tak jak Adela Wilczek, budownicza kopalni „Ziemowit II” - wyrastały na „symbol równouprawnienia kobiety, która na równi z armią mężczyzn walczy o nowe, szczęśliwe jutro naszej Ojczyzny"89. Symbolem równouprawnienia była również Maria Rakowa, która zrujnowane gospodarstwo sióstr zakonnych zamieniła w doskonale prosperujący $\mathrm{PGR}^{90}$. Obok przodowników pracy promowani byli przodownicy w nauce, którzy - jak Czesław Nycz, uczeń Technikum Mechanicznego w Warszawie - zrozumieli, „jak wielką rolę odgrywają w Planie 6-letnim kadry" ${ }^{\prime \prime}$. Na miano bohaterów zasługiwali też chłopi-patrioci, szczególnie tacy, którzy - jak biedny chłop Cieśliński - realizowali swój obowiązkowy plan dostaw produktów rolnych z naddatkiem ${ }^{92}$. Nieodłącznym elementem prezentacji wspomnianych bohaterów było zwrócenie szczególnej uwagi na ich życiorys. W większości przypadków był on zgodny z tym, co napisano w poniższym fragmencie artykułu: „to ludzie, którzy mają za sobą gorzkie dzieciństwo, bezradosną młodość, lata bezrobocia, krzywdy, nędzy. Świadomość klasowa narastała w nich podczas walk strajkowych, w dniach bezrobocia, głodu i bezdomności, wreszcie zaś - w okresie okupacji, w podziemnej walce z najeźdźcą hitlerowskim, służby w wojsku polskim i pracy dla odbudowy"ق3. W przypadku bohaterów z młodszych roczników okazywało się, że nakreślonym wyżej życiorysem mógł się pochwalić ojciec lub matka bohatera ${ }^{94}$.

Odrębną kategorię bohaterów dnia codziennego stanowili aktywiści społeczni, a zwłaszcza dekonspiratorzy wroga klasowego. Chętnie publikowano przykłady takich działań jak np. czyn ZMP-owców z 11-letniej szkoły ogólnokształcącej ze Skierniewic, którzy, klasyfikując swojego nauczyciela jako wroga ludu, doprowadzili do zwolnienia go z pracy ${ }^{95}$.

Definicja wroga nie była klarowna. Mógł nim zostać każdy, kto swoimi działaniami zakłócał proces budowy Polski Ludowej. Najgroźniejszą grupę stanowili jawni przeciwnicy ustroju, których procesy sądowe $z$ upodobaniem relacjonowano na łamach prasy, w tym m.in.: członkowie tzw. grupy Tatara czy bp. Cz. Kaczmarek $^{96}$. Szerokim echem społecznym odbiła się również sprawa "bandy Burmajstra” - grupy chłopców oskarżonych o działalność rabunkowo-terrorystyczną, a donie-

${ }^{88}$ Dlaczego osiągam 250\% normy, P 1952, nr 17, s. 5; A. Ł a d y ń s k i, Brawo kolego Gadziński!, P 1950, nr 4, s. 5; Dobrze zasłużyli się Ludowej Ojczyźnie, P 1949, nr 31, s. 6-7.

${ }^{89}$ M. De r b i én, Spotkanie z Adelą Wilczek, P 1953, nr 2, s. 7.

90 [K.G.], Kobiety Polski Ludowej-gospodarstwo Marii Rakowej, NW 1951, nr 9, s. 1.

91 Przedstawiamy delegatów na Zlot „Przodujący Uczeń”, P 1952, nr 27, s. 8.

92 Chłopi-patrioci, NW 1951, nr 46, s. 6.

${ }_{93}^{3}$ [K.K.], Co czytać, Pł 1950, nr 16, s. 253; Z. Ko r ta, Dzień Seweryna Juszczaka, P 1953, nr 1, s. 6; [I.R.], Piękny dzień, NW 1951, nr 40, s. 6-7.

94 M. D e r b i e ń, Spotkanie..., s. 7; Ochotnicy z zaciągu pionierskiego z kopalni „Bolesław Chrobry", P 1953, nr 6, s. 6-7; Życiorys jakich wiele, P 1953, nr 22, s. 8.

95 Sprawa nauczyciela, P 1950, nr 40, s. 11.

96 T. Kurek, Katechizm zdrady, P 1953, nr 5, s. 2; J. Se gel, Zdrajcy, P 1952, nr 1, s. 4; Wszystkie drogi zdrady, P 1952, nr 3, s. 9; Z. J u r k i e w i c z, Kłąb ohydy i zbrodni. Na marginesie krakowskiego procesu, P 1952, nr 3, s. 6; Służyli wojnie, P 1951, nr 32, s. 2; [J.W.], Mordercy i szpiedzy ukarani, NW 1951, nr 43, s. 4. 
sienia $z$ ich procesu sądowego były treścią niejednego artykułu prasowego ${ }^{97}$. $\mathrm{Na}$ miano wrogów zasługiwali też nauczyciele-reakcjoniści, jak wspomniany nauczyciel Wacław Boczkowski ze Skierniewic czy księża-katecheci, którzy - jak prefekt Biały z liceum pedagogicznego w Pułtusku - nie podpisali Apelu Pokoju ${ }^{98}$. Postępek księdza dał z kolei asumpt do napisania przez młodzież tej szkoły otwartego listu, w którym czytamy, co następuje: „Od nauczyciela wymagamy [...] wychowywania nas w duchu walki o pokój. Ksiądz Biały natomiast wielokrotnie usiłował na naszych lekcjach poderwać w nas wiarę w skuteczność walki o pokój. Tym samym - ludzie tacy nie mogą nas wychowywać. Nie pozwolimy na to właśnie my, młodzież" ${ }^{\prime \prime}$. Powyższy list był zresztą tylko elementem zmasowanej akcji, w ramach której komitety rodzicielskie poszczególnych szkół pisały rezolucje żądające usuwania ze szkół księży-katechetów - przeciwników państwa ludowego ${ }^{100}$.

Charakteryzując wrogów młodzieży, specjalną uwagę poświęcono bumelantom: zarówno tym z zakładów pracy, jak np. Wielogórskiemu i Bereziukowi z kopalni „Bobrek”101, jak i tym ze szkół, np. Tadeuszowi Marcinkowskiemu z liceum warszawskiego ${ }^{102}$. Odpowiednikiem bumelanta w fabryce czy szkole stawał się na wsi kułak. Postulowano: „na każdym kroku zrywać maskę z kułaka, piętnować jego wrogą postawę"103. Podobnie jak w przypadku członków band, tak i tutaj podawano do wiadomości publicznej zarówno nazwiska, jak i wysokość wyroku sądowego ${ }^{104}$. Odrębną kategorię wrogów ludowej Ojczyzny stanowili bikiniarze, których ubiór i zachowanie były przedmiotem zajadłej krytyki, a pojedyncze przypadki, jak Henryka Wandeita z liceum w Otwocku ${ }^{105}$, były poddawane prasowemu zbiorowemu linczowi. Praktyce takiej poddano również Leona Mańkę, przedstawiciela ostatniej z grup antybohaterów dnia codziennego, tj. tych, którzy okazali się zdrajcami przyjętych przez siebie wcześniej ideałów. Leon Mańka był ZMP-owcem i korespondentem „Nowej Wsi”, który po ochotniczym zgłoszeniu się do brygady PO SP zdezerterował z budowy. Na apel gazety przyszło około 300 listów, zgodnie potępiających czyn Leona Mańki i domagających się jego usunięcia z szeregów ZMP ${ }^{106}$. Cel propagandowy został osiągnięty.

Na końcu można zadać pytanie o rolę, jaką w propagandowym przekazie odgrywały figury bohatera i wroga. Po pierwsze, ich obecność wynikała z dogmatu o dychotomicznym podziale rzeczywistości na świat dobra i postępu oraz świat zła i wstecznictwa. Opowiedzenie się „po jasnej stronie mocy” gwarantowa-

97 E. Wa c ow s k a, Wilki w owczej skórze, SzM 1951, nr 270, s. 2; K. O b o r s k a, Za zbrodnie - surowe kary, tamże, nr 272, s. 2; Bądźmy czujni! List otwarty młodzieży klasy IV b Technikum Mechaniczno-Teletechnicznego w Warszawie do młodzieży całego kraju, tamże, nr 273, s. 1; J. W u n d e rl i c h, „Bikiniarstwo” - chuligaństwo - zbrodnia. Oto droga Burmajstra i innych, tamże, nr 274, s. 2.

${ }_{98}$ C. Łu czyńs ki, S. G ołaś, W. Dą b row s ki, On NIE podpisał, P 1950, nr 24, s. 4.

99 Tamże.

100 Ci, którzy nie chcą pokoju, nie będą nas uczyć i wychowywać, ŚM 1950, nr 26, s. 5.

101 Bumelanci, P 1953, nr 14, s. 8.

102 SzM 1951, nr 25, s. 3.

103 Jak kułacy Bojanowski i inni wykonują swoje obywatelskie obowiązki, NW 1951, nr 46, s. 3, 5.

104 Kary więzienia dla kułaków - wrogów Polski Ludowej, NW 1951, nr 45, s. 4.

105 SzM 1951, nr 298, s. 5.

106 Sprawa Leona Mańki, NW 1953, nr 33, s. 5. 
ło urzeczywistnienie się wizji świeckiego raju na ziemi. Po drugie, istnienie bohaterów i wrogów pełniło funkcję integracyjną i umacniającą wobec kreowanego porządku społeczno-politycznego. Bohaterzy infantylizowali społeczeństwo, gdyż ukazywali nieporadność przeciętnego obywatela wobec tych, co wiedzą lepiej i więcej i z tej przyczyny to oni mieli wskazywać kierunek marszu. Bohaterowie polityki, sportu, kultury, nauki i życia codziennego stanowili gotowe wzorce do naśladowania, a zarazem potencjalne antidotum na zgubne oddziaływania wroga państwa ludowego. $Z$ kolei wrogowie stanowili odpowiedni kontrast dla doskonałości promowanych bohaterów, których dokonania zdawały się jeszcze bardziej imponujące. Co więcej, kreowanie wrogów było niezbędne, aby legitymizować unieszkodliwianie ludzi, których system uznał za szkodliwych czy groźnych. Nie można również zapomnieć o istotnym wymiarze praktycznym: istnienie wrogów i ich domniemane knowania tłumaczyło każde niepowodzenie władzy, co w ostatecznym rozrachunku uzasadniało trwanie systemu i związanych z nim represji. 